\title{
Research on flux of dry atmospheric falling dust and its characterization in a subtropical city, Guangzhou, South China
}

\author{
Jinping Zhao • Ping'an Peng • Jianzhong Song • \\ Shexia Ma • Guoying Sheng • Jiamo Fu
}

Received: 6 September 2009 /Accepted: 22 December 2009 / Published online: 2 February 2010

(C) The Author(s) 2010. This article is published with open access at Springerlink.com

\begin{abstract}
Guangzhou is the central city in the Pearl River Delta (PRD), China, and is one of the most polluted cities in the world. To characterize the ambient falling dust pollution, two typical sampling sites: urban (Wushan) and suburban (University Town) areas in Guangzhou city were chosen for falling dust collection over 1 year at time intervals of 1 or 2 months. The flux of dry deposition was calculated. In addition, mineral composition and morphology of atmospheric falling dust were studied by X-ray diffraction, scanning electron microscopy, and microscopic observation. The results revealed that the dust flux in Guangzhou city was $3.34-3.78 \mathrm{~g} /\left(\mathrm{m}^{2}\right.$ month $)$ during the study period. The main minerals in the dust were quartz, illite, calcite, kaolinite, gypsum, plagioclase, dolomite, and amorphous matter. The morphological types included grained and flaky individual minerals, chain-like aggregates, spherical flying beads, and irregular aggregates, with the chain-like and spherical aggregates indicators of industrial ash. The major dusts were derived from industrial and construction activities. The gypsum present in the dust collected in winter season was not only derived from cement dust but may also have originated from the reaction of calcic material with sulfuric acids resulting from photooxidation of $\mathrm{SO}_{x}$ and $\mathrm{NO}_{x}$, which confirmed serious air pollution due to $\mathrm{SO}_{x}$ and $\mathrm{NO}_{x}$ in Guangzhou. The abatement of fossil fuel combustion
\end{abstract}

\footnotetext{
J. Zhao $\cdot$ P. Peng $(\triangle) \cdot J$. Song $\cdot \mathrm{S}$. Ma $\cdot$ G. Sheng $\cdot$ J. Fu

State Key Laboratory of Organic Geochemistry,

Guangzhou Institute of Geochemistry,

Chinese Academy of Sciences,

Guangzhou 510640, People's Republic of China

e-mail: pengpingan@sina.com

J. Zhao

Key Lab of Urban Environment and Health, Institute of Urban Environment, Chinese Academy of Sciences, Xiamen 361021, People's Republic of China
}

emissions and construction dust will have a significant beneficial effect on dust reduction.

Keywords Dry falling dust · Flux · Inorganic mineral . $\mathrm{XRD} \cdot \mathrm{SEM}$

\section{Introduction}

In recent years, worldwide concerns over air quality have increased research in the area of atmospheric particulate characterization (Boevski et al. 2000; Donahue et al. 2009). Atmospheric falling dust is a generalized component of atmospheric particles, which are particles fallen to the ground due to their own gravitation. The diameter of these particles is more than $10 \mu \mathrm{m}$ and less than $100 \mu \mathrm{m}$. From an aerodynamic point of view, pollutants which are carried by falling dust may cause near-source pollution resulting from dust particles which are easily deposited. Therefore, dust deposition has important significance as an indicator of environment quality (Vento and Dachs 2007; Wang 2003).

Atmospheric falling dust has a complex mineral and chemical composition because it is derived from different sources and processes (Abed et al. 2009; Chen and Xu 2003). Falling dust particles may provide reaction sites for many heterogeneous reactions involving $\mathrm{SO}_{2}, \mathrm{NO}_{x}, \mathrm{O}_{3}$, etc. and serve as conveyors carrying anthropogenic substances a distance from their sources (Sullivan et al. 2007). Such reactions could cause certain modifications in the properties of both dust and anthropogenic aerosols. Therefore, studies on sources, compositions, and the content of falling dust are necessary for the risk assessment of dust to atmospheric quality, ecology, and human health. The characterization of falling dust is also relevant in the study of global climate change because the degree of the dust-climate effects are 
dominated by the chemical and physical properties of mineral particles, including their type, size, chemical composition, morphology, and particle number concentration (Sokolik and Toon 1999). These effects have sparked interest in atmospheric falling dust, and it has become an object for multidisciplinary study such as environmental science, environmental engineering, atmospheric physics and chemistry, and geochemistry (Menon et al. 2002; Vento and Dachs 2007).

Atmospheric falling dust includes dry and wet dust, of which wet dust has been widely researched and documented in the literature (Hope 2008; Chantara and Chunsuk 2008). Research into the process of dry deposition is obviously weaker than that of wet deposition (Sabin and Schiff 2008; Wang 2003), and measurements of dry falling dust and its mineral constituents in atmospheric particles in Guangzhou are scarce and limited. A detailed characterization of dry falling dust is also lacking in samples collected from urban areas or suburban areas in this region.

The purpose of this work was to measure the flux of dry falling dust in Guangzhou. Analyses were carried out using X-ray diffraction (XRD), scanning electron microscopy (SEM), microscopic observation, and particle size distribution; mineral constituents, morphological characteristics and possible sources of the dusts in Guangzhou were also studied. The characterization of dry falling dust would have significance for air pollution control in Guangzhou.

\section{Experimental}

\section{Sample collection}

Dust samples were collected from two sites in Guangzhou city, PR China: Wushan (WS) in Tianhe district and University Town (UT) in Panyu district.

WS represents an urban area and is surrounded by highways, schools, residential buildings, office buildings, and industrial factories. The main sources of air pollution at this site are thought to be anthropogenic. Samples were collected on the roof of a library building $18 \mathrm{~m}$ above the ground.

UT represents a suburban area and is located at the boundary between urban and rural areas and surrounded by many universities. The main sources of air pollution at this site are a mixture of anthropogenic and biological. Samples were collected on the roof of a five-storey building in South China Normal University $23 \mathrm{~m}$ above the ground.

The roof of each building was selected for sampling as it received natural falling dust and avoided secondary fugitive dust. The sampling sites were cleaned when one sample collection was finished and the next sample is collected.
The dust collected passed a $0.28-\mathrm{mm}$ sieve to remove large leaf debris and stored in a brown bottle containing desiccators until use. Falling dust was collected for 1 year at time intervals of 1 or 2 months at WS and UT between April 2006 and May 2007. A total of 16 samples were collected.

\section{Methods}

Flux of dry falling dust

In order to determine the contribution of dry falling dust to the environment, the flux of the falling dust $\left(\mathrm{g} / \mathrm{m}^{2}\right)$ was calculated. The flux was calculated using the following equation for atmospheric falling dust: $D=M / A$, where $D$ is the deposition flux in gram per square meter, $M$ is the weight $(\mathrm{g})$ of the dry falling dust during each sampling period, and $A$ is the area of the sampling sites in square meter.

\section{X-ray diffraction}

Mineralogical analyses of atmospheric falling dusts were performed using XRD. XRD tests were conducted using a Japan-made D/MAX-IIIA powder diffractometer with a Bragg-Bentano $\theta: 2 \theta$ configuration, using a $\mathrm{Cu}$ target tube and a graphite monochromator. Samples were analyzed within the range $10-70^{\circ}$, with two tube voltage $10 \mathrm{kV}$, tube electric flow $30 \mathrm{~mA}$, scan rate $10 \% \mathrm{~min}$, and a wide sampling step $0.02^{\circ}$. XRD plots and MDI Jade 5 software were used for peak recognition, mineral identification, and peak intensity calculations.

\section{Petrographic examination}

The facies, shapes, and sizes of the falling dust were also examined under an optical microscope (Leitz MPV-3) in two different modes: reflected and fluorescent; the latter was induced by blue light excitation (546 nm). Thin sections of the falling dust were used for examinations in fluorescent mode and were prepared by evenly spreading falling dust powders onto glass slides, which were then cemented with glycerol and covered with a cover glass. The polished sections used for the reflected and fluorescent modes were prepared by spreading the dust powders onto porcelain slides and cementing the powders with low-fluorescence 502 mucilage glue. The slides were then thin-sectioned and polished.

Scanning electron microscopy

The sizes, morphology, and elemental composition of falling dust particles in different samples were examined 
using a Japan-made S-3700 N SEM with Oxford Link INCA 300 energy-dispersive spectrometer (EDS).

Particle size measurement

A Beckman Coulter LS 13320, a laser diffraction-based particle size analyzer, was used to measure particle size. In order to avoid dissolution of particles in water, a dry powder system was used for this measurement. The Beckman Coulter LS 13320 software (version 5.01) was used for operation and data analyses. Particle sizes ranging from 0.375 to $2,000 \mu \mathrm{m}$ in diameter were measured. All particle sizes reported here were based on the volume distribution of the particles.

\section{Results and discussion}

The flux of atmospheric falling dust

Many scientists have studied the source and the physical and chemical properties of atmospheric particulate matter (Hueglin et al. 2005; Shi et al. 2006). The studies in the literature on falling dust have mainly focused on dust storm events, such as the studies on dust particle size influenced by sea salt during dust storms, and long-distance transmission of dust (Zhang and Iwasaka 2004; Lee et al. 2007). Although some studies have reported dust flux (Sauret et al. 2009), inorganic mineral composition (Krueger et al. 2004), and particle size distribution (Iijima et al. 2007), the majority of studies in the Chinese literature have concentrated on the northern Loess Plateau cities (Zhang et al. 2006; Sun et al. 2001) and not on falling dust in southern large- and mediumsized cities, such as Guangzhou.

It can be seen from Table 1 that the flux value for each month ranged from 1.90 to $9.36 \mathrm{~g} /\left(\mathrm{m}^{2}\right.$ month), with an average monthly flux of $3.34-3.78 \mathrm{~g} /\left(\mathrm{m}^{2}\right.$ month), and the yearly flux was $40.10-45.36 \mathrm{~g} /\left(\mathrm{m}^{2}\right.$ year $)$. These data are higher than those reported by Inomata et al. (2009), who studied the dry deposition fluxes in Tsukuba, a coastal city in Japan and found that the flux was $0.08-3.00 \mathrm{~g} /\left(\mathrm{m}^{2}\right.$ month). The monthly changes in flux for falling dust between WS and UT was variable. There was a higher flux of falling dust in October 2006 than in the other sampling months in UT because there was a construction site near the UT sampling site around October, which may have contributed to the higher flux found during that month, whereas the flux of falling dust in May 2006 in WS was higher than in any other month, which may have been due to frequent haze days which exacerbated the pollution of dust deposition in the spring of 2006 in WS.

During the year, we can see that the lower flux value was in September at the urban sampling site, which may have
Table 1 Flux of dry atmospheric falling dust in WS and UT during May 2006-May 2007

\begin{tabular}{|c|c|c|}
\hline Sampling time (month/year) & WS $\left(g / m^{2}\right)$ & $\mathrm{UT}\left(\mathrm{g} / \mathrm{m}^{2}\right)$ \\
\hline May 2006 & 4.17 & 2.53 \\
\hline September 2006 & 2.87 & 4.43 \\
\hline October 2006 & 3.83 & 9.36 \\
\hline December 2006 & 2.45 & 2.99 \\
\hline January 2007 & 3.33 & 4.76 \\
\hline March 2007 & 3.13 & 1.90 \\
\hline May 2007 & 3.07 & 1.56 \\
\hline Average flux in summer month ${ }^{\mathrm{a}}$ & $2.48 \pm 5.58^{\mathrm{b}}$ & $2.58 \pm 2.54$ \\
\hline Average flux in winter month ${ }^{\mathrm{a}}$ & $3.58 \pm 1.34$ & $4.74 \pm 1.95$ \\
\hline Average monthly flux & $3.34 \pm 0.45$ & $3.78 \pm 1.91$ \\
\hline Average flux for the year & 40.10 & 45.36 \\
\hline
\end{tabular}

${ }^{a}$ Guangzhou is governed by monsoon weather, and therefore the year can be divided into two seasons, e.g., summer and winter. Summer included May, June, July, August, September, and October; winter included November, December, January, February, March, and April ${ }^{\mathrm{b}}$ Average $\pm \mathrm{SD}$

been associated with frequent rain and less accumulated particulate matter during the summer in Guangzhou. WS, the urban sampling site, was mainly affected by a large volume of traffic, and the concentrations of particulate matter pollution from vehicle exhaust emission as well as road dust were not clearly different in the two seasons; therefore, there was no obvious change in the monthly flux. However, the suburban site, UT, was not only influenced by anthropogenic activity but also by biological activity (e.g., agricultural activity). Therefore, changes in falling dust flux in UT were obviously higher each month than that in WS. According to the seasonal variation in dust flux, we can also see that dust pollution in the winter season was higher than that in the summer season (Table 1). The fluxes of falling dust in UT in winter and summer were 4.74 and $2.58 \mathrm{~g} /\left(\mathrm{m}^{2}\right.$ month), respectively. The reasons for this difference may be due to the strong winds and dry climate conditions which led to an increase in dust deposition in winter. On the other hand, frequent temperature inversion and haze days in the winter in Guangzhou also provided atmospheric conditions for cumulative particulate matter in Guangzhou, whereas frequent rain in summer decreased dust pollution.

A previous study (Sun et al. 2001) indicated that the normal level of falling dust in the Loess Plateau may reflect the background characterization of particulate matter in atmospheric dust from the origin area to the deposition region, which was mainly controlled by high-altitude airflow. Falling dust occurred during dust storm events mainly controlled by monsoon circulation which was only transported in the near-surface airflow. In the southern cities which are away from sources of dust storms, the normal 
falling dust therefore reflected the background characterization of particulate matter in the atmosphere in the deposition region and was controlled by regional anthropogenic activity and low atmospheric circulation. The falling dust flux in the suburban area indicated that it was influenced by near sources from anthropogenic and biological activity much more than far sources which are contributed by high-altitude atmospheric circulation.

Minerals in atmospheric falling dust

Atmospheric falling dust with a complex mineral composition was the deposition of atmospheric aerosols, which had complex sources that can be divided into natural and anthropogenic sources. Atmospheric falling dusts are different in particulate morphology and mineral composition, and the sources of the falling dust can be determined (Chen and $\mathrm{Xu}$ 2003; Zhang et al. 2009; Gomez et al. 2004).

Figure 1 shows representative XRD spectra of the samples from WS and UT. The minerals contained in the falling dust can be determined by their $2 \theta$ angle of the diffraction peak. Similarly, relative mineral content can be estimated using the intensity of diffraction peaks. The error was less than $10 \%$. The semiquantitative analysis of minerals is shown in Table 2.
The main minerals in Guangzhou dry falling dust were quartz, gypsum, calcite, plagioclase, illite, kaolinite, dolomite, and amorphous material.

Illite and other clay minerals are water-bearing silicate minerals, which are unstable in a high-temperature environment. Therefore, it is not possible for illite to exist in industrial smoke or dust, the existence of such minerals in dry falling dust indicated that the source of the dust was from the ground which contributed to atmospheric particulate matter. Quartz and plagioclase as silicate minerals are stable under high temperature and can be present in industrial smoke. Quartz is also a common mineral in all soils. Road dust may therefore be another main source of quartz. Kaolinite, calcite, and dolomite may exist in fugitive dust from ground and industrial dusts. The sources of quartz, plagioclase, kaolinite, calcite, and dolomite can be further identified by morphology. The amorphous material in atmospheric particulate matter is a typical product of a high-temperature process, and therefore these amorphous matters can be used as a marker of industrial smoke and dust. As discussed in the following section, most quartz, plagioclase, kaolinite, calcite, and dolomite minerals were present in the samples in an amorphous state. Therefore, they were mostly derived from anthropogenic activities and only
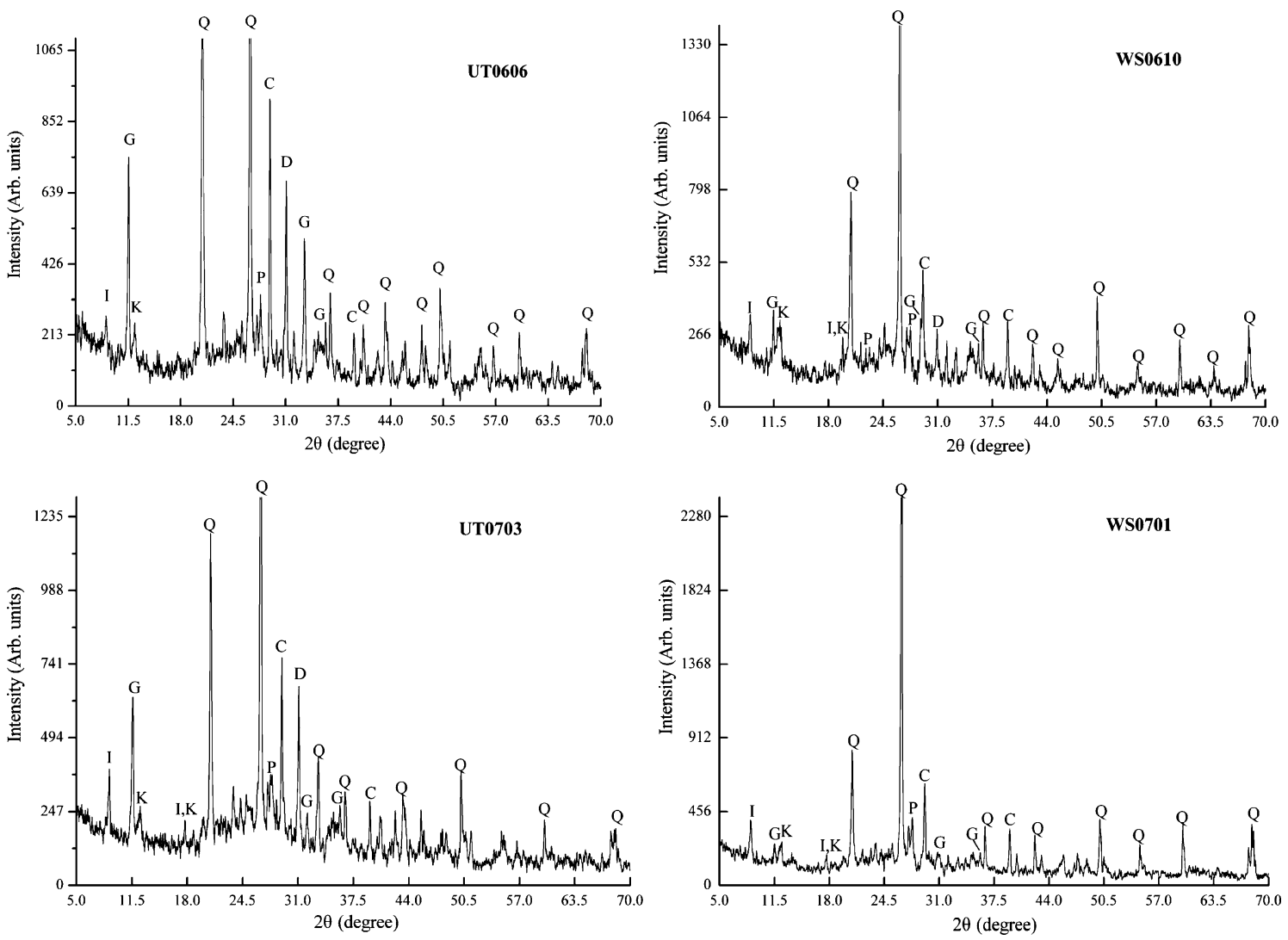

Fig. $1 \mathrm{XRD}$ of the atmospheric falling dust. $I$ illite, $G$ gypsum, $C$ chlorite, $K$ kaolinite, $Q$ quartz, $P$ plagioclase, $C$ calcite, $D$ dolomite. Samples were named according to the sampling site (UT, WS) and

sampling time (year and month). For example, UT0606 means that the sample was collected in UT in June 2006 
Table 2 Composition and relative content of minerals in dry falling dust in WS and UT, Guangzhou $\left(W_{\mathrm{B}} / \%\right)$

\begin{tabular}{|c|c|c|c|c|c|c|c|}
\hline Samples & Quartz & Gypsum & Calcite & Plagioclase & Illite & Kaolinite & Dolomite \\
\hline \multicolumn{8}{|l|}{ WS } \\
\hline Average for summer ${ }^{a}$ & $80.9 \pm 2.8^{b}$ & $3.8 \pm 1.4$ & $9.8 \pm 2.7$ & $2.1 \pm 0.4$ & $1.3 \pm 0.3$ & $0.9 \pm 0.3$ & $2.4 \pm 0.3$ \\
\hline Average for winter & $80.8 \pm 1.9$ & $5.0 \pm 1.1$ & $9.5 \pm 1.3$ & $2.5 \pm 1.0$ & $1.4 \pm 0.6$ & $0.9 \pm 0.4$ & $0.0 \pm 0.0$ \\
\hline Average for whole year & $80.9 \pm 2.5$ & $4.4 \pm 1.4$ & $9.7 \pm 2.1$ & $2.3 \pm 0.8$ & $1.3 \pm 0.5$ & $0.9 \pm 0.4$ & $2.4 \pm 0.3$ \\
\hline \multicolumn{8}{|l|}{ UT } \\
\hline Average for summer & $73.2 \pm 5.9$ & $7.9 \pm 3.4$ & $10.3 \pm 2.5$ & $2.7 \pm 1.1$ & $1.7 \pm 0.8$ & $1.2 \pm 0.5$ & $3.9 \pm 1.5$ \\
\hline Average for winter & $76.0 \pm 3.2$ & $9.0 \pm 2.2$ & $8.6 \pm 2.4$ & $1.7 \pm 0.2$ & $1.5 \pm 0.2$ & $1.0 \pm 0.1$ & $5.0 \pm 0.9$ \\
\hline Average for whole year & $74.6 \pm 5.0$ & $8.5 \pm 2.9$ & $9.4 \pm 2.6$ & $2.2 \pm 1.0$ & $1.6 \pm 0.6$ & $1.1 \pm 0.4$ & $4.4 \pm 1.4$ \\
\hline
\end{tabular}

${ }^{\text {a }}$ Summer included May, June, July, August, September, and October; winter included November, December, January, February, March, and April ${ }^{\mathrm{b}}$ Average $\pm \mathrm{SD}$

partly from the soil. General similarities of mineral composition in dust of WS and UT support this conclusion (Table 2). If dust were derived from the soil, the mineral composition would change geographically (Belozerova 2009).

However, a recognizable gypsum peak, occurring in the XRD spectra, was in the samples collected in winter from UT. It is known that gypsum is a common additive in cements at a concentration less than 4\% (Panigrahy et al. 2003; Chen 2008). Therefore, a higher percentage of gypsum in UT samples shown in Table 2 demonstrated that the gypsum was not only from construction dust, but most of the gypsum was formed from the reaction of sulfuric acids with calcic material. This indicated the serious emission of $\mathrm{SO}_{x}$ and $\mathrm{NO}_{x}$ and photochemical oxidation of $\mathrm{SO}_{x}$ and $\mathrm{NO}_{x}$ into corresponding acids in Guangzhou.

From Table 2, we also can see that the average relative content of quartz in UT was lower than that in WS, which may be associated with high gypsum in UT.

\section{Petrographic examination analysis}

Atmospheric falling dusts were identified based on the characteristics observed under the petrographic microscope in reflected and fluorescent modes. Major observations and
Fig. 2 Microphotographs of falling dust under reflecting (ref.) and fluorescent (flu.) mode microscopy. UT0609, UT0612, WS0609, WS0701, and WS0703 represent falling dust samples collected in UT in September and December 2006 and in WS in September 2006 and January and March 2007. "-1" and "-2" represent the first and second microphotographs of the same sample. a Organic matter with dendritic structure; b pyrites with yellowish color; c spherical black carbon with cellular structure; d amorphous quartz with high reflectance; e black carbon with macroporous and dendritic structures and vitrinite macerals with low reflectance; f plant cell walls with high fluorescence; $\mathbf{g}$ clay mineral and feldspar with medium reflectance; $\mathbf{h}$ gypsum with smooth surface and slimlined structure. i amorphous flocculation (e.g., fly ash) with low reflectance and gypsum with medium reflectance

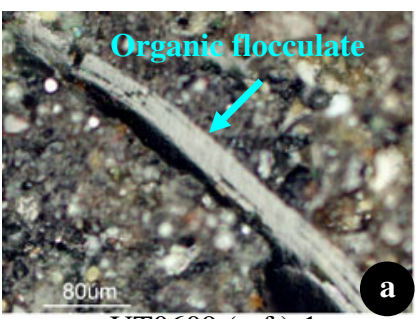

UT0609 (ref.)-1

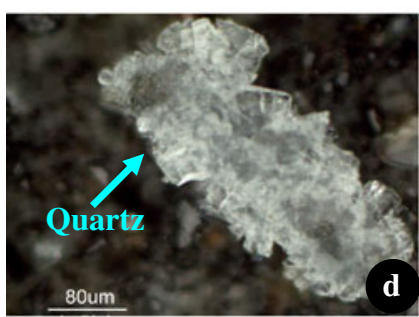

UT0612 (ref.)-2

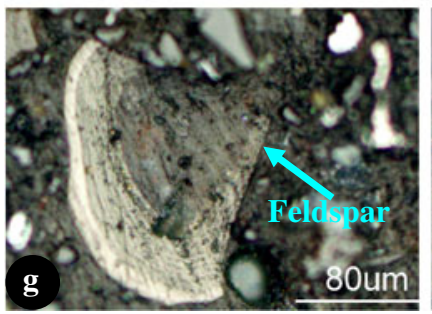

WS0701 (ref.)

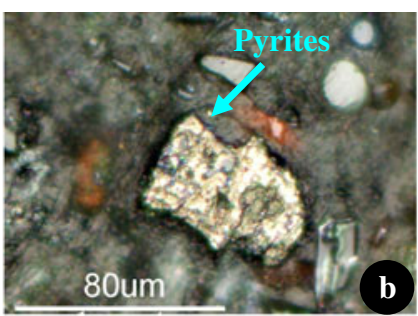

UT0609 (ref.)-2

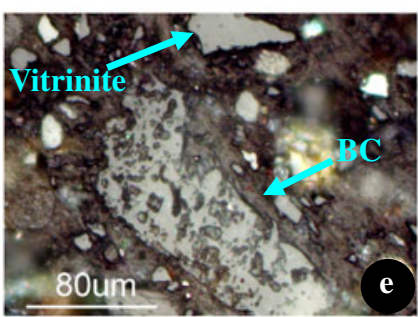

WS0609 (ref.)

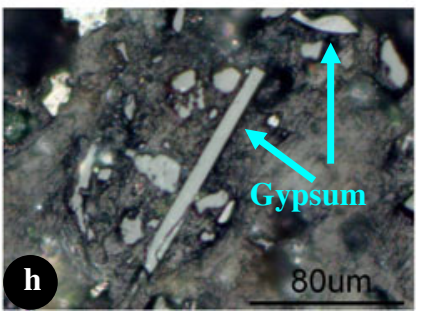

WS0703 (ref.)-1

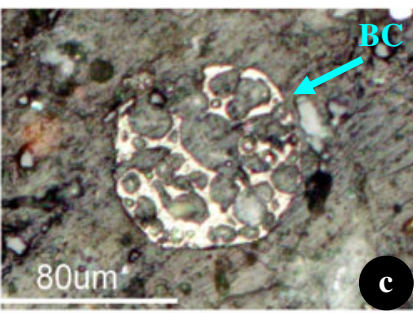

UT0612 (ref.)-1

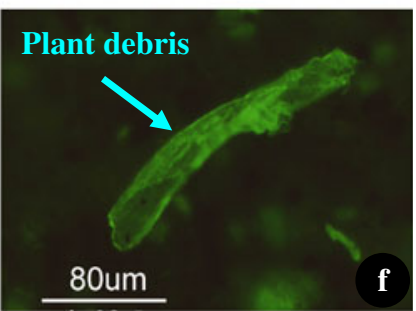

WS0609 (flu.)

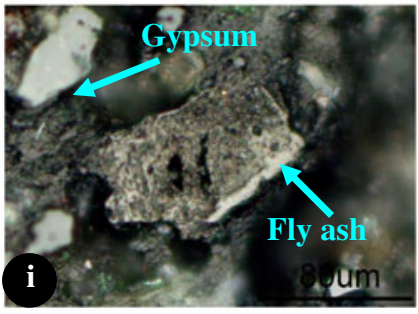

WS0703 (ref.)-2 
representative appearance, shape, and partial minerals are shown in Fig. 2.

Char-black carbon which had a spherical and hole-shaped structure (UT0612-1 and WS0609 in Fig. 2) was the most common particle in the falling dust samples, which had a strong light reflectance similar to that of fusinite structure. There was also irregular organic matter that showed branch bark structure (UT0609-1 in Fig. 2); its intensity of light reflectance was lower than the reflected light of fusinite. WS0703-1 showed abundant gypsum with a smooth surface and medium reflectance, which was formed from cement dust or the reaction of sulfuric acids with calcic mineral. WS0703-2 was possibly amorphous organic flocculation that may have originated from automobile exhaust or factory
Fig. 3 Scanning electron microscopic photographs of the dry falling dust (a) BC particle with different minerals (UT0609).

b Large BC particle with a smooth, spherical-shaped surface and macroporous structures (WS0609). c BC particles with irregular shapes and amorphous organic flocculation on the $\mathrm{BC}$ and with mineral particles situated in holes (WS0609). d Fly ash particles with smooth, spherical-shaped structures and with mineral particles situated in holes (WS0701). e BC particle with layered structures and with mineral particles or fly ash situated in holes (WS0701). f $\mathrm{BC}$, amorphous organic flocculation with elongated/ layered structures and a flat surface (UT0612). g Fly ash with mineral particles situated in holes. h Different minerals with elongated/layered structures and a flat surface (UT0612)
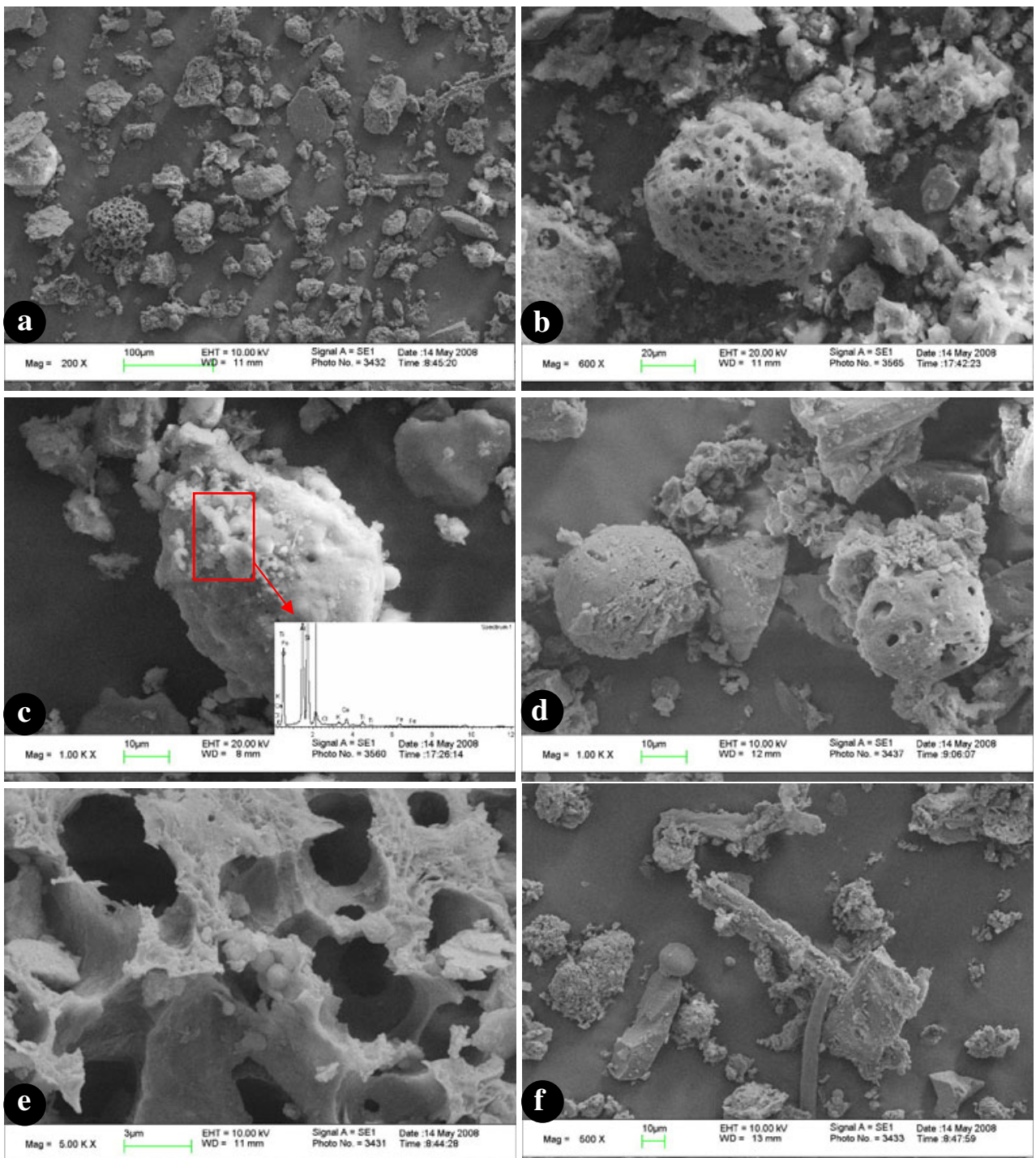

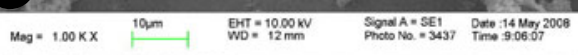
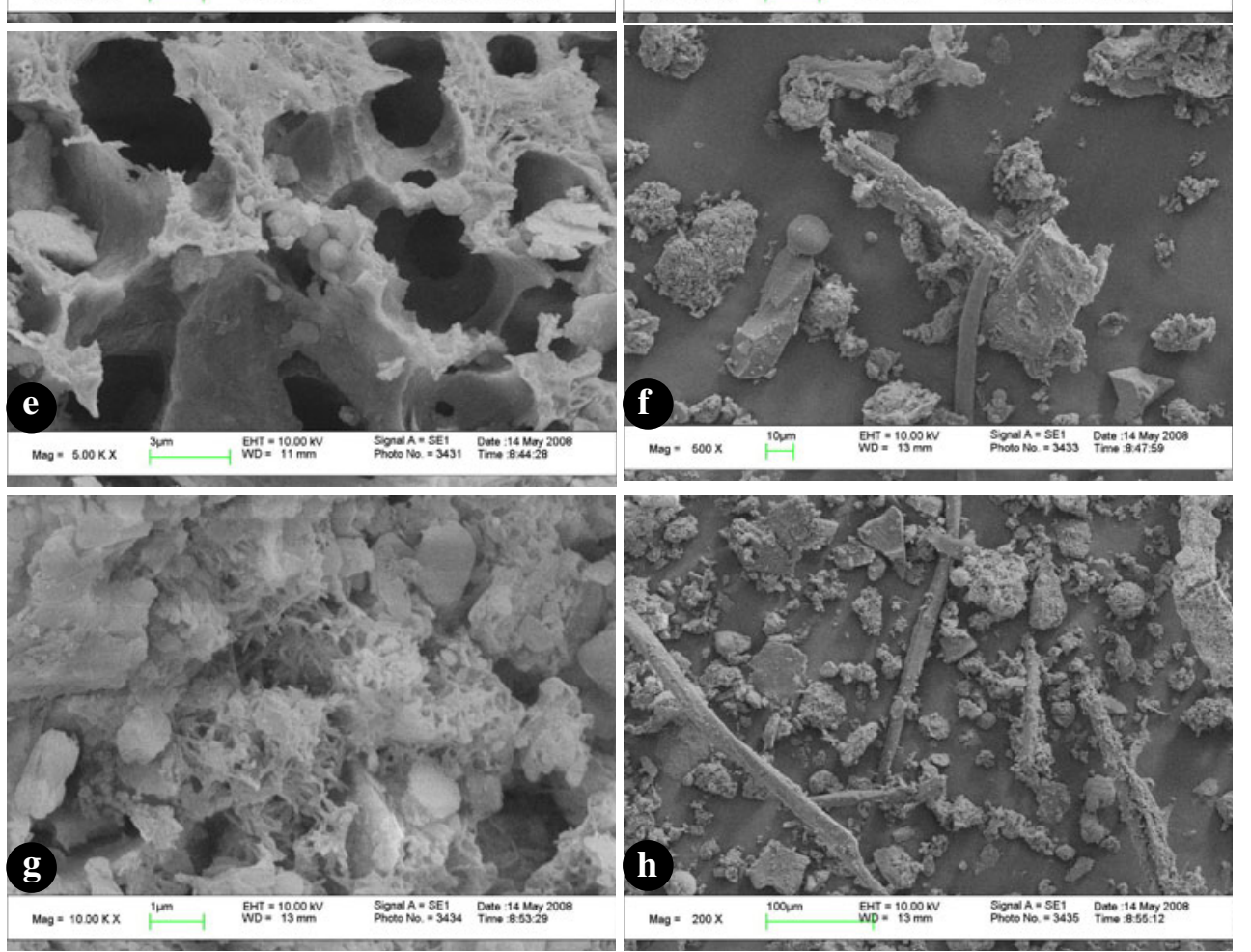
chimney pollutant emissions. Quartz also had a very strong light reflectance under reflected microscopy (UT0612-2 in Fig. 2) and had an irregular shape and smooth surface with a high-temperature origin.

The shapes of other materials and inorganic minerals under reflected light were varied (UT0609-1 and UT0609-2 in Fig. 2) and displayed different light reflectance. UT0609-2 contained pyrite, which indicated the dust contribution from coal combustion in power plants. The organic matter in WS0609 (flu.) was transparent under fluorescence microscopy which showed information on the cell wall of plants.

Based on the observations under the microscope, we can conclude that anthropogenic activity was the main source contributing to dust pollution in WS and UT sampling sites.

\section{Scanning electron microscopy analysis}

Figure 3 shows SEM images of four falling dust samples which illustrate the diversity of dust particulate matter. (1) Monomineral with a sheet or granular structures (Fig. 3a-d). These particulate matters may be attributed to clay mineral particles according to their morphology, which represented a source of dust from the ground. (2) Chain-like aggregates (Fig. 3a, g, h) with a large number of submicron particle compositions. Kasparian et al. (1998) and Bérubé et al. (1999) thought that these aggregates were soot aggregates and automobile exhaust particles. (3) The sizes of alveolate and spherical cenosphere particles (Fig. 3b, d, e) were variable; some reached more than $10 \mu \mathrm{m}$ and were derived from diesel exhaust or coal-fired fly ash. According to EDS (Fig. 3c) analysis, the main composition of these spherical floating particles were $\mathrm{O}, \mathrm{K}, \mathrm{Si}$, and $\mathrm{Al}$, with a small amount of $\mathrm{Cl}, \mathrm{S}, \mathrm{Ca}$, and $\mathrm{Ti}$, which were derived from soot from coal-fired plants. This result was consistent with the findings of Okada et al. (2005). (4) The irregular granular aggregates (Fig. 3h) may have been derived from ground dust or from construction dust. It is interesting to note that the spherical fly ash particles shown in Fig. 3c were hollow glass particles, which are a distinctive indicator of coal combustion.
The large and relatively compact soot particle in Fig. 3b shows the morphology and size of soot particles which reflected the influence of anthropogenic sources, in particular fossil fuel burning, which was the main constituent of this falling dust. In addition, biomass burning may be another source of soot, whose characteristic shape was similar to that of laminated sheets (Fig. 3e and f); however, the contribution of biomass burning was less than that of fossil fuel burning, which also suggested that industrial activity was the main source affecting dust pollution in the urban and suburban areas of Guangzhou.

According to the results of the EDS analysis, mineral particles were mainly quartz, gypsum, calcite, and the aluminum silicate minerals (e.g., kaolinite, montmorillonite). Due to limitations in the experimental conditions, we could not detect the entire mineral composition. However, we have seen that the mineral composition of atmospheric particulate matter is complex and has many more mineral types than detected by Quinn et al. (2004).

\section{Particle size analysis}

Table 3 shows the volume percentages of different particle sizes in the dust. The size distribution was bimodal, with a pronounced peak at 1.15-2.01 and 27.39-36.21 $\mu \mathrm{m}$, with the exception of UT0703 which was dominated by particles size of $18.86 \mu \mathrm{m}$. Table 3 also shows that the diameter of the main particles in falling dust in Guangzhou ranged from 20 to $50 \mu \mathrm{m}$. Particle sizes less than 50, 10, and $3 \mu \mathrm{m}$ accounted for $100 \%, 13.4-24.7 \%$, and $2.8-13.7 \%$ of the total particles, respectively (Table 3 ). Thus, it can be seen that the pollution of inhalable particles (dynamics diameter less than $10 \mu \mathrm{m}, \mathrm{PM}_{10}$ ), which is harmful to human health, is serious in Guangzhou.

\section{Conclusions}

Based on the flux and characterization studies of dust samples collected at urban and suburban sites in Guangzhou

Table 3 The grain size of falling dust in Guangzhou city

\begin{tabular}{|c|c|c|c|c|c|c|c|c|}
\hline \multirow[t]{2}{*}{ Samples } & \multicolumn{7}{|c|}{ Relative contents of different-sized particles $(V / \%)$} & \multirow[t]{2}{*}{ Average size $(\mu \mathrm{m})$} \\
\hline & $\geq 50 \mu \mathrm{m}$ & $20-50 \mu \mathrm{m}$ & $10-20 \mu \mathrm{m}$ & $5-10 \mu \mathrm{m}$ & $3-5 \mu \mathrm{m}$ & $1-3 \mu \mathrm{m}$ & $\leq 1 \mu \mathrm{m}$ & \\
\hline WS0609 ${ }^{\mathrm{a}}$ & 0 & 37.5 & 27.4 & 15.2 & 5.4 & 9.5 & 5.0 & 16.2 \\
\hline WS0703 & 0 & 39.7 & 26.8 & 13.4 & 5.0 & 9.8 & 5.3 & 16.7 \\
\hline UT0609 & 0 & 29.0 & 28.9 & 21.7 & 7.2 & 8.6 & 4.6 & 14.4 \\
\hline UT0612 & 0.03 & 43.3 & 29.8 & 15.3 & 5.3 & 2.8 & 3.5 & 18.6 \\
\hline UT0703 & 0 & 10.2 & 34.8 & 24.7 & 9.0 & 13.7 & 7.6 & 9.8 \\
\hline
\end{tabular}

${ }^{\mathrm{a}}$ For sample numbers, see Table 1 
from April 2006 to May 2007, the following conclusions can be drawn:

1. The average monthly fluxes of dry falling dust in WS and UT were $3.34-3.78 \mathrm{~g} /\left(\mathrm{m}^{2}\right.$ month $)$, and the mean yearly flux was $40.10-45.36 \mathrm{~g} /\left(\mathrm{m}^{2}\right.$ year $)$. The dust flux in the winter season was higher than that in the summer season.

2. XRD analysis showed that the inorganic minerals in dry falling dust were quartz, illite, calcite, kaolinite, gypsum, plagioclase, dolomite, and amorphous matter, of which quartz accounted for the highest proportion and gypsum was also high. The massive amount of gypsum detected in the samples from UT suggested the presence of $\mathrm{SO}_{x}$ pollution in the suburban of Guangzhou.

3. Petrographic examinations and SEM analyses indicated that there were high levels of organic matter in the dust in addition to inorganic minerals such as gypsum and clay. They had higher reflectance of black carbon and fly ash particles and lower reflectance of amorphous organic matter. The composition and morphology of minerals and organic matter provided information on the source of the dust. Granular and sheet single minerals were markers of road dust, and chain aggregates and spherical particles were markers of industrial smoke dust, while irregular granular aggregates were markers of construction dust.

Our results indicated that most dust compositions in Guangzhou were derived from anthropogenic activities. Therefore, the abatement of fossil fuel combustion emissions and construction dust will have a significant beneficial effect on dust reduction in Guangzhou. This will improve air quality since $13.4-24.7 \%$ (in volume) of dusts are $\mathrm{PM}_{10}$ which is harmful to human health.

Acknowledgments This work was supported by the National Natural Science Foundation of China (no. 40505026) and the Chinese Academy of Sciences (KZCX2-YW-403). The authors would like to thank Prof. Dehan Liu and Jiagui Shen of Guangzhou Institute of Geochemistry, CAS, for their technical assistance in the petrographic examination. The anonymous reviewer is thanked for their comments.

Open access This article is distributed under the terms of the Creative Commons Attribution Noncommercial License which permits any noncommercial use, distribution, and reproduction in any medium, provided the original author(s) and source are credited.

\section{References}

Abed AM, Kuisi MA, Khair HA (2009) Characterization of the Khamaseen (spring) dust in Jordan. Atmos Environ 43(18):28682876. doi:10.1016/j.atmosenv.2009.03.015

Belozerova OY (2009) Investigation of soil mineral component in the Baikal Region by X-ray electron probe microanalysis. Spectro- chim Acta Part B 64(11-12):1248-1252. doi:10.1016/j.sab. 2009.09.009

Bérubé KA, Jones TP, Williamson BJ, Winters C, Morgan AJ, Richards RJ (1999) Physicochemical characterisation of diesel exhaust particles: factors for assessing biological activity. Atmos Environ 33(10):1599-1614. doi:10.1016/S1352-2310(98)00384-7

Boevski IV, Daskalova N, Havezov I (2000) Determination of barium, chromium, cadmium, manganese, lead and zinc in atmospheric particulate matter by inductively coupled plasma atomic emission spectrometry (ICP-AES). Spectrochim Acta Part B At Spectrosc 55(11):1643-1657. doi:10.1016/S0584-8547(00)00265-2

Chantara S, Chunsuk N (2008) Comparison of wet-only and bulk deposition at Chiang Mai (Thailand) based on rainwater chemical composition. Atmos Enviro 42(22):5511-5518. doi:10.1016/j. atmosenv.2008.03.022

Chen GB (2008) Determination of optimum dosage for gypsum in cement plaster. Fujian Build Mater 106(5):46-47 (In Chinese)

Chen TH, Xu HF (2003) TEM investigation of atmospheric particle settlings and its significance in environmental mineralogy. Acta Petrol Mineral 22:425-428 (In Chinese)

Donahue NM, Robinson AL, Pandis SN (2009) Atmospheric organic particulate matter: from smoke to secondary organic aerosol. Atmos Environ 43(1):94-106. doi:10.1016/j.atmosenv.2008.09.055

Gomez ET, Sanfeliu T, Jordan M, Rius J, de la Funente C (2004) Geochemical characteristics of particulate matter in the atmosphere surrounding a ceramic industrialized area. Environ Geo 45(4):536543. doi:10.1007/s00254-003-0908-9

Hope BK (2008) A model for the presence of polychlorinated biphenyls (PCBs) in the Willamette River Basin (Oregon). Environ Sci Technol 42(16):5998-6006. doi:10.1021/es8000213

Hueglin C, Gehrig R, Baltensperger U, Gysel M, Monn C, Vonmont H (2005) Chemical characterization of PM2.5, PM10 and coarse particles at urban, near-city and rural sites in Switzerland. Atmos Environ 39(4):637-651. doi:10.1016/j.atmosenv.2004.10.027

Iijima A, Sato K, Yano K, Tago H, Kato M, Kimura H, Furuta N (2007) Particle size and composition distribution analysis of automotive brake abrasion dusts for the evaluation of antimony sources of airborne particulate matter. Atmos Environ 41 (23):4908-4919. doi:10.1016/j.atmosenv.2007.02.005

Inomata Y, Igarashi Y, Chiba M, Shinoda Y, Takahashi H (2009) Dry and wet deposition of water-insoluble dust and water-soluble chemical species during spring 2007 in Tsukuba, Japan. Atmos Environ 43(29):4503-4512. doi:10.1016/j.atmosenv.2009.06. 048

Kasparian J, Frejafon E, Rambaldi P, Yu J, Vezin B, Wolf JP, Ritter P, Viscardi $P$ (1998) Characterization of urban aerosols using SEMmicroscopy, X-ray analysis and Lidar measurements. Atmos Environ 32(17):2957-2967. doi:10.1016/S1352-2310(98)00013-2

Krueger BJ, Grassian VH, Cowin JP, Laskin A (2004) Heterogeneous chemistry of individual mineral dust particles from different dust source regions: the importance of particle mineralogy. Atmos Environ 38(36):6253-6261. doi:10.1016/j.atmosenv.2004.07.010

Lee SJ, Park H, Choi SD, Lee JM, Chang YS (2007) Assessment of variations in atmospheric PCDD/Fs by Asian dust in Southeastern Korea. Atmos Environ 41(28):5876-5886. doi:10.1016/j. atmosenv.2007.03.025

Menon S, Hansen J, Nazarenko L, Luo YF (2002) Climate effects of black carbon aerosols in China and India. Sci 29:2250-2253. doi:10.1126/science.1075159

Okada K, Qin Y, Kai KJ (2005) Elemental composition and mixing properties of atmospheric mineral particles collected in Hohhot, China. Atmos Res 73(1-2):45-67. doi:10.1016/j. atmosres.2004.08.001

Panigrahy PK, Goswami G, Panda JD, Panda RK (2003) Differential comminution of gypsum in cements ground in different mills. Cem Concr Res 33(7):945-947. doi:10.1016/S0008-8846(02)00992-4 
Quinn PK, Coffman DJ, Bates TS, Welton EJ, Covert DS, Miller TL, Johnson JE, Maria S, Russell L, Arimoto R, Carrico CM, Rood MJ, Anderson J (2004) Aerosol optical properties measured on board the Ronald H. Brown during ACE-Asia as a function of aerosol chemical composition and source region. J Geophys Res 109(19):D19S01.1-D19S01.28. doi:10.1029/2003JD004010

Sabin LD, Schiff KC (2008) Dry atmospheric deposition rates of metals along a coastal transect in southern California. Atmos Environ 42(27):6606-6613. doi:10.1016/j.atmosenv.2008. 04.042

Sauret N, Wortham H, Strekowski R, Herckès P, Nieto LI (2009) Comparison of annual dry and wet deposition fluxes of selected pesticides in Strasbourg, France. Environ Pollut 157(1):303-312. doi:10.1016/j.envpol.2008.06.034

Shi YX, Dai XR, Song ZG, Yu LZ, Guan ZZ (2006) Particle size distribution and mineral components of atmospheric particles collected in spring of Shanghai. J Des Res 26(5):780-785 (In Chinese)

Sokolik IN, Toon OB (1999) Incorporation of mineralogical composition into models of the radiative properties of mineral aerosol from UV to IR wavelengths. J Geophy Res 104(8):9423-9444
Sullivan RC, Guazzotti SA, Sodeman DA, Prather KA (2007) Direct observations of the atmospheric processing of Asian mineral dust. Atmos Chem Phys 7:1213-1236

Sun DH, Su RX, Chen FH, David R (2001) Composition, susceptibility and input flux of present aeolian dust over loess plateau of China. Acta Geogr Sin 56(2):171-180 (In Chinese)

Vento SD, Dachs J (2007) Atmospheric occurrence and deposition of polycyclic aromatic hydrocarbons in the northeast tropical and subtropical Atlantic ocean. Environ Sci Technol 41(16):56085613. doi:10.1021/es0707660

Wang ZH (2003) The research on the aerolion dust deposition monitoring. J Arid Land Resour Environ 17(1):54-59 (In Chinese)

Zhang D, Iwasaka Y (2004) Size change of Asian dust particles caused by sea salt interaction: measurements in southwestern Japan. Geophys Res Lett 31(15):1-4. doi:10.1029/2004GL020087

Zhang CJ, Hu YX, Qian YY (2006) A study of the characteristics and source of the atmospheric deposition dust in Lanzhou. J Lanzhou Univ (Nat Sci) 42(6):39-44 (In Chinese)

Zhang RJ, Han ZW, Cheng TT, Tao J (2009) Chemical properties and origin of dust aerosols in Beijing during springtime. China Particuology 7(1):61-67. doi:10.1016/j.pardc.2008.11.003 